\title{
An immigrant's experience: science is a discipline without borders
}

\author{
Ivor J. Benjamin
}

Cardiovascular Center, Medical College of Wisconsin, Milwaukee, Wisconsin, USA.

A immigrant background, I am pleased to share my journey, a few perspectives about the current immigration climate, and observations warranting our collective attention going forward. In 1998, I accepted an invitation to an international conference on stress responses and molecular chaperones held in Kyoto, Japan (1). I presented work from my laboratory at the University of Texas Southwestern Medical Center in Dallas, which had exploited gene-targeting technology to study the effects of the first genetic knockout of heat shock transcription factor 1 (HSF1), the master regulator of dozens of stress proteins (2-4). One of the conference hosts, distinguished molecular biologist Takashi Yura, and I struck up a conversation that, among other things, touched on our diverse backgrounds. Takashi Yura graciously shared his experiences as a foreign student in the United States for his doctoral studies (Yale, $\mathrm{PhD}, 1957$ ) and his postdoctoral studies before returning to Japan. While the implications were profoundly prescient to me as one of few Black scientists in my field, and as an immigrant to the United States myself, I never forgot Takashi Yura telling me that science is a discipline without borders. Indeed, similar words were later penned by Elias Zerhouni, himself an Algerian immigrant who trained in diagnostic radiology at Johns Hopkins, and later served as NIH Director (5).

\section{My voyage from Guyana with} a twist

I was born and raised in Guyana, South America, and my family helped me start this journey by moving to the United States after I graduated from high school. In addi-
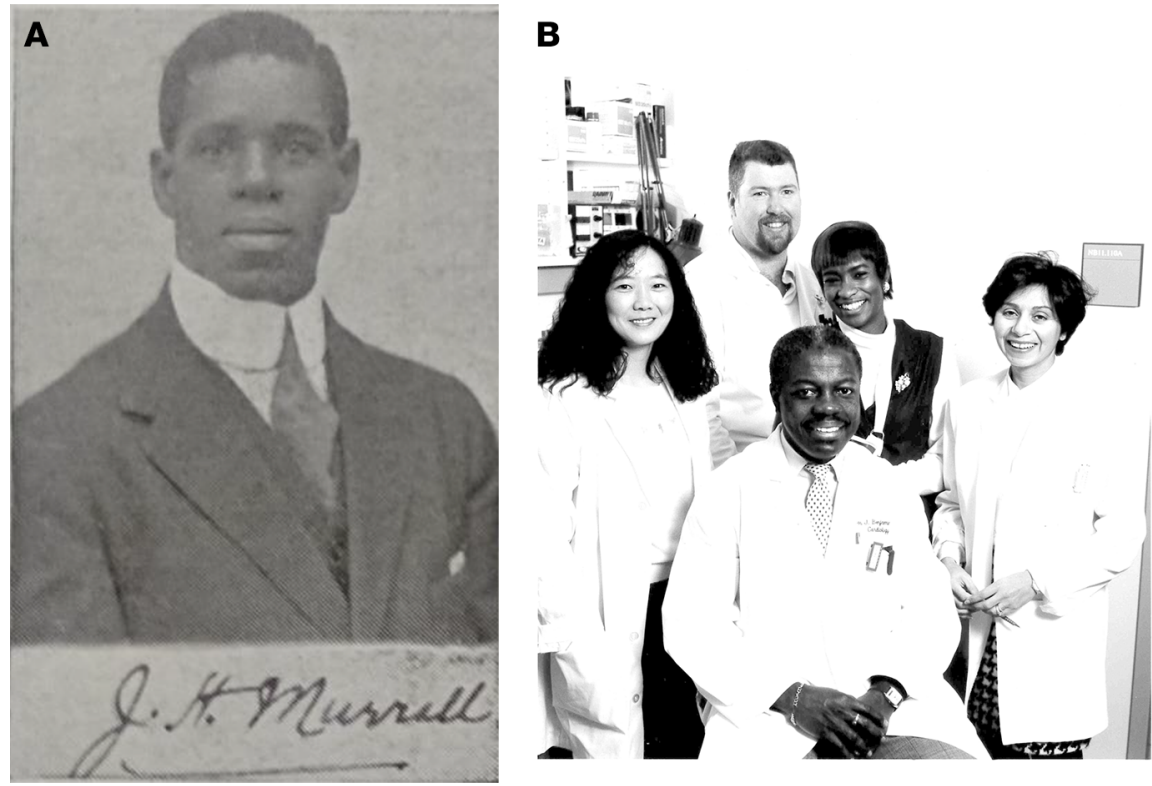

Figure 1. Select people who influenced my journey. (A) James Henry Murrell, circa 1921. (B) Ivor Benjamin, with his laboratory at the University of Texas Southwestern Medical Center in 1994.

tion to the steps my parents took to give me this opportunity, I am even more humbled that I am not the first physician in my family to have undertaken international training and work. My grandmother's brother, James Henry Murrell (Figure $1 \mathrm{~A})$, inspired my confidence and courage as I embarked my own journey. My middle name, James, is in his honor. James Henry Murrell was a young man when he left Guyana for schooling in Battle Creek, Michigan. He went on to the University of Edinburgh, Scotland, where he earned his medical degree in 1921. After this, he moved to Ghana where he performed the first blood transfusion in West Africa. $\mathrm{He}$ was a touchstone throughout my childhood and, perhaps, his legacy continues to be witnessed by several of his great nieces and nephews who, emulating him, have entered the medical profession.

\section{My undergraduate years and research exposure}

I arrived in New York City in the early 1970s, and I enrolled in the closest branch of the City University of New York, Hunter College. Luckily for me, Hunter proved to be more than just another school. It was a vibrant, multicultural, urban campus with a rich tradition of academic excellence. Fellow alumni include pioneers, such as Nobel Laureates Rosalyn Yalow and Gertrude Elion, as well as one of the first physicians to focus on heart disease in women, Nanette Wenger. At Hunter, I made a quick study of both the formal and informal networks used to overcome the obstacles and critical steps to navigate the system from two influential figures, both with immigrant backgrounds. I took an upper-level sociology class with Aubrey Bonnet who introduced me to Frank L. Douglas, who had $\mathrm{PhD}$ in physical chemistry from Cornell University and was completing medical school at Weill Cornell in New York City.

Frank advised me that good grades are necessary but are not sufficient for 
entrance into research-intensive medical schools. So, I joined Edwin Abbott's chemistry laboratory, surrounded primarily by postdoctoral fellows from India, with whom I shared mutual interests in sports, with a particular passion for cricket. Because my first peek at science made me want to dig deeper, I found a path that led to a summer program at Weill Cornell Medicine (now known as the Travelers Summer Research Program). Although it was only four blocks from my college campus, entering the medical school environment was like entering a new world. After all those years of hearing about my uncle, it was as if he were tapping on my shoulder and saying, "Welcome. This is where you belong." Ultimately, I joined the biochemistry laboratory run by Daniel Wellner at Weill Cornell, where I was introduced to questions that continue to challenge practitioners in cardiovascular physiology.

\section{My experience at Johns Hopkins}

In 1978, I began medical school at Johns Hopkins. Frank Douglas was now a senior resident at Hopkins and introduced me to Bernadine Healy. In addition to serving among my predecessors as president of the American Heart Association, Bernadine went on to become the first woman to serve as director of the NIH. Under her tutelage, I published my first paper in Circulation (6), a retrospective pathologic study of the taxonomy of idiopathic dilated cardiomyopathy. Another enduring impression during this period came from Levi Watkins. Levi, a native son of Alabama, became a civil rights activist while in medical school at Vanderbilt, and remained a powerful voice in his years as a cardiac surgeon at Hopkins. In 1980, Levi became the first surgeon to successfully implant an automatic cardiac defibrillator in a human patient. He strongly and successfully advocated increases in the racial and ethnic diversity of students admitted to the Johns Hopkins School of Medicine. I had the great pleasure of accompanying him on several recruiting trips. After my internal medicine residency at Yale-New Haven Hospital, Levi's mentorship led me down another important path in my career, to what is now known as The Harold Amos Medical Faculty Development Program of the Robert Wood Johnson Foundation.

\section{Early-stage investigator}

The Harold Amos program was formed to address the limited opportunities for people from historically disadvantaged backgrounds to pursue academic careers. The Foundation created this vehicle to increase opportunities for these individuals to become leaders among medical faculties (7). With the Amos award, I had the wherewithal to dive deeper into basic cardiovascular research. As an early-stage Black scientist, I acknowledge the essentiality of my mentor and lifelong friend, Sandy Williams. I joined Sandy's lab as a postdoctoral fellow at Duke University and I subsequently followed him to UT Southwestern Medical Center in Dallas. Sandy and I built a mutual respect and trust that forged our deep professional relationship and provided a safe space to explore my personal challenges when confronted with racism and white privilege. I'd be remiss not to mention that Augustus Grant, himself an immigrant and another of my predecessors as president of the American Heart Association, introduced me to Sandy.

As I began to build my independent laboratory (Figure 1B), I felt empowered in what has become a lifelong pursuit of answering fundamental questions about the mechanisms in biological systems. For example, I was able develop the first Hsf1-knockout mouse sought after and used by hundreds of scientists worldwide, which explains why it was selected by The Jackson Laboratory for distribution to the global community (010543-C; 129 Hsfl $\left.{ }^{\text {tmijb }} / \mathrm{J}\right)$. Likewise, our research team was the first to demonstrate that reductive stress - in contrast with oxidative stress - could also be a paradigm for human pathobiology as a causal mechanism in human proteinmisfolding (R120G CryAB) cardiomyopathy (8). Indeed, this paved the way for my receipt of an NIH Director's Pioneer Award to study protein-misfolding cardiomyopathy and oxido-reductive stress.

\section{A key role for mentors}

As mentioned earlier, my career has been shaped by many wonderful mentors. While I've mentioned several by name, there are many more, including Lawrence Cohen, Karl Weber, Augustus Grant, and Mike Weisfeldt. In a recent article, Robert Lefkowitz, who shared the Nobel Prize for Chemistry in 2012 with Brian Kobilka, affectionately refers to his scientific "children" (e.g., former trainees Sandy Williams and Brian Kobilka), in regard to which I am honored to be included among countless numbers of Robert Lefkowitz's "scientific grandchildren" (9). Accumulating evidence has shown that diverse teams achieve higher levels of scientific excellence, research impact, and solutions to complex problems (10). While talent is equally distributed across human populations, opportunity is not. Is the next asylum seeker, who is housed in a cage at the border, being robbed of her dreams to become the next cancer researcher or cardiovascular scientist?

\section{The global stage: president of the American Heart Association}

In my 2018 presidential address at the American Heart Association Scientific Sessions, the preeminent gathering for professionals from around the globe allied in the fight against heart disease and stroke, I decried the appalling decline of individuals, especially of Black men, entering the field of cardiovascular science and medicine. I remain concerned about the dwindling numbers of Black or African American scientists and physicians. In the year I applied to medical school - 1978 - I was among approximately 1,400 Black men to do so. As of 2014, the number of medical school applications made by Black men had dropped to about 1300. Even though the US population has grown, and more Black men are graduating from college, far fewer see themselves entering the medical and allied science fields. As a result, only $3.6 \%$ of biological and medical sciences faculty are African American (11).

\section{Opportunities and challenges for underrepresented groups}

From my current position as an established physician-scientist and director of the Cardiovascular Center at the Medical College of Wisconsin, I continue to strongly advocate for increasing training and mentoring opportunities, from STEM to implementation research, for underrepresented groups (URGs) and for inclusive research to stem health disparities. I remain committed to building a pathway for future scientists by serving as formal external advisor/mentor for multidisciplinary investigators from 
URGs. Years ago, having been mentored so well myself, I began mentoring undergraduate students. In the course of this I have mentored men and women who are Black, Hispanic, Asian, White, rich, poor, inbetween, and of various ages, religions, and sexual orientations. Given the disproportionately low numbers of Black scientists with active research labs, I am on a mission to demonstrate that science is better when diverse voices are represented and to offer tangible evidence that URGs belong here. That said, we must address our broken immigration policy that robs millions of DACA (Deferred Action of Childhood Arrivals) recipients from citizenship, precluding their unfettered contributions to science and humankind.

While the United States is the best place for launching scientific pursuits and careers, evidence for discordance between the distribution of talent in the population and career opportunities remains, especially for Black Americans and other people of color (10). This is a national tragedy. Considerable attention is now focused on structural racism, defined as the totality of ways that society fosters racial discrimination via inequitable systems (e.g., housing, education, health care). This systematic inequity continues to reinforce and perpetuate a lack of diversity and talent in scientific endeavors and injustices within the research community (12-14).

A century ago, following World War I and the 1918-1919 pandemic, Europe was dominated by headwinds of nationalism and changes in the political climate, pre- saging the mass exodus and unspeakable mayhem of World War II. One of my academic heroes, Eugene Braunwald, himself an Austrian Jewish émigré who landed in New York City via England, became perhaps the most celebrated and influential cardiologist of the last half-century. It is estimated that immigrants comprise over $40 \%$ of the United States cancer-related and biomedical workforce (15), ushering in the extraordinary biomedical advances the world has enjoyed during the past half-century.

Indeed, cultural and ethnic diversity is enriching. Takashi Yura's words continue to ring true for me today: "Ivor, science is a discipline with no borders.” It is my story, too.

\section{Acknowledgments}

I wish to thank Rose Marie Robertson, John Lough, David Gutterman, Balaraman Kalyanaraman, and Allison DeVan for their helpful suggestions and comments for this article.

Address correspondence to: Ivor J. Benjamin, Professor \& Director, Cardiovascular Center, Medical College of Wisconsin, 8701 Watertown Plank Road, Milwaukee, Wisconsin 53226, USA. Phone: 414.955.6716; Email: ibenjamin@mcw.edu.

1. Yoshida M, et al. Dynamics and regulation of the stress response: meeting report on the stress response and molecular chaperones from Kyoto. Cell Stress Chaperones. 1999;4(1):66-74.

2. McMillan DR, et al. Targeted disruption of heat shock transcription factor 1 abolishes thermotolerance and protection against heat-inducible apoptosis. J Biol Chem. 1998;273(13):7523-7528.

3. Xiao X, et al. HSF1 is required for extraembryonic development, postnatal growth and protection during inflammatory responses in mice. ЕMBO J. 1999;18(21):5943-5952.

4. Christians E, et al. Maternal effect of Hsf1 on reproductive success. Nature. 2000;407(6805):693-694.

5. Zerhouni EA. International medical graduates in the United States: a view from an ECFMG certificant. Acad Med. 2006;81(12 suppl):S40-S42.

6. Benjamin IJ, et al. Cardiac hypertrophy in idiopathic dilated congestive cardiomyopathy: a clinicopathologic study. Circulation. 1981;64(3):442-447.

7. Ardery NL, et al. Leveraging diversity in American academic medicine. The Harold Amos medical faculty development program. Ann Am Thorac Soc. 2014;11(4):600-602.

8. Rajasekaran NS, et al. Human alpha B-crystallin mutation causes oxido-reductive stress and protein aggregation cardiomyopathy in mice. Cell. 2007;130(3):427-439.

9. Lefkowitz R. The Art of Scholarly Mentoring. https://www.insidehighered.com/ advice/2021/01/26/nobel-laureate-shares-10rules-being-effective-mentor-young-researchscholars. Updated January 26, 2021. Accessed March 22, 2021.

10. Gomez LE, Bernet P. Diversity improves performance and outcomes. J Natl Med Assoc. 2019;111(4):383-392.

11. Association of American Medical College. Diversity in Medicine: Facts and Figures 2019. https:// www.aamc.org/data-reports/workforce/report/ diversity-medicine-facts-and-figures-2019. Accessed March 22, 2021.

12. Stevens KR, et al. Fund black scientists. Cell. 2021;184(3):561-565.

13. Ginther DK, et al. Race, ethnicity, and NIH research awards. Science. 2011;333(6045):1015-1019.

14. Barber PH, et al. Systemic racism in higher education. Science. 2020;369(6510):1440-1441.

15. Gewin V. Cancer researcher defends immigrant scientists. Nature. 2018;562(7727):451. 